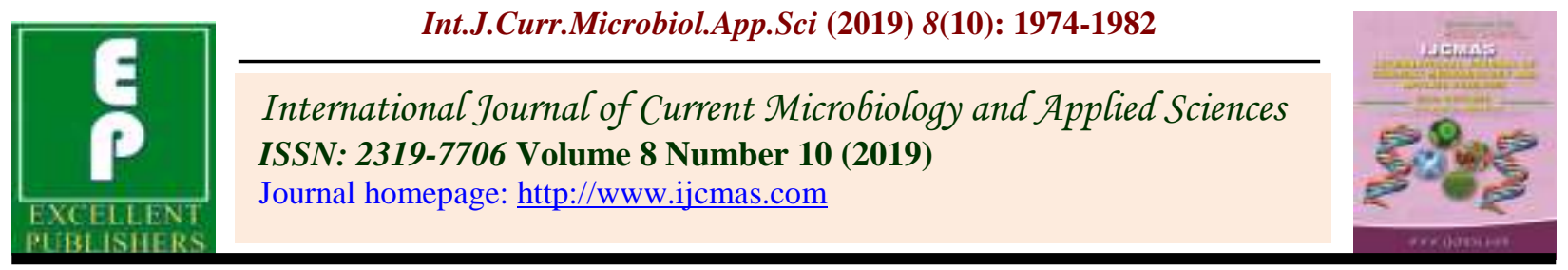

Original Research Article

https://doi.org/10.20546/ijcmas.2019.810.230

\title{
An Analytical Study on the Production and Export of Indian Agricultural Crop with Reference to Wheat
}

\author{
Tarandeep Singh*
}

Guru Nanak Dev Engineering College, Ludhiana, India

*Corresponding author

\begin{tabular}{|l|}
\hline Ke y w o r d s \\
Wheat production, \\
Wheat export, \\
Agriculture, Curve- \\
Fitting, ANOVA \\
\hline Article Info \\
\hline $\begin{array}{l}\text { Accepted: } \\
15 \text { September } 2019 \\
\text { Available Online: } \\
10 \text { October } 2019\end{array}$ \\
\hline
\end{tabular}

\section{Keywords}

Wheat production Wheat export, Agriculture, Curveting, ANOVA

Article Info

Accepted:

Available Online:

10 October 2019

\section{A B S T R A C T}

Agriculture is one of the most important sectors for India. It is considered as the backbone of the Indian Economy. About 18\% of the GDP is dependent upon agriculture. In terms of agricultural production, India is one of the largest producers of wheat, rice, spices, spice products and pulses. About $55 \%$ of the population depends on agriculture for its nutrition. Agriculture being prone to risks is in the need of new policies, strategies, enhanced investment to sustainably increase its production of agricultural products. Not only India, needs to focus upon its production, but also needs to increase its export of agricultural products. Agribusiness needs to evolve to change the state of Indian Agriculture. The study conducted in this research paper is focused on the Indian agricultural crop wheat with reference to the production and export of wheat in India. It will help to understand the state of agriculture with respect to wheat in India and pave paths to new research areas by understanding the analytical relationship between the both.

\section{Introduction}

Wheat is the $2^{\text {nd }}$ most important crop for India over which $55 \%$ population depends upon for its nutrition. For North India, wheat is one of the most important staple foods. Wheat's popularity lies in its high protein content and wide adaptability to environmental conditions. [9].

There are different varieties of wheat that are grown all over the world. The classification of wheat is based on growth habits, species and commercial types. Based on such classification there are 2 commercial varieties of wheat: Bread and Duran Wheat or Macroni, 16 varieties based on species and 3 based on growth habits: spring wheat, facultative wheat and winter habit wheat. [7]

The varieties of wheat mainly grown in India are HS-240,VL-804, HS-365, HD2687,VL832, WH-147, WH-542, WH-896(d), PBW343,, PDW-233(d), PBW-502 , UP-2338, 
Shresth (HD 2687), HW-2044, Aditya (HD 2781), HW-1085, HW-741, NP-200(di). [6]

In terms of agriculture production, India holds one of the strongest positions at the global platform. India is at the second position in wheat production next to China. India's global market share in wheat is about $12 \%$ next to China's share of $17 \%$. Northern States like Punjab and Haryana are at the top in production of wheat in India. Other states that produce wheat include Madhya Pradesh, Gujarat, Rajasthan, Bihar and Uttar Pradesh.

Russia has emerged as the single largest exporter of wheat across the world. Only 4 decades ago, Russia was dependent on US for its wheat imports with the support of government, rich soil and proximity to ports in Black Sea, Russia has seen this large change over a small span of time. Other strong exporters include Canada, US, Australia. India's export of wheat contributes to only $0.1 \%$ of the market share. Major importers of wheat from India are Nepal, Bangladesh, United Arab Emirates and Sri Lanka.

Indonesia, Egypt and Algeria are the top importers of wheat in the world contributing to $6.1 \%, 5.3 \%$ and $4.4 \%$ to the global market share respectively. India also imports wheat from other countries like Russia, Australia and Ukraine. India's import of wheat contributes to $0.05 \%$ market share. $[1,2,3,4]$

\section{Hypothesis of the study}

\section{Null hypothesis}

India is one of the largest producers of wheat in the world and also one of the largest exporters of wheat in the world.

\section{Alternative hypothesis}

India is one of the largest producers of wheat in the world but as compared to production, India is not a very big exporter of wheat.
The primary objectives of this study are listed below:

To study the production of wheat in India; To study the export of wheat from India and to analyse the analytical relationship between the production and export of wheat in India.

\section{Materials and Methods}

\section{Data collection}

The researcher has used secondary data for this study. Secondary data is basically primary data collected by someone else. Researchers use this data for their research purposes. Here researcher has used data from UN Comtrade, as reported by the importing countries, Food and Agricultural Organisation (FAO), Ministry of Agriculture, Govt. of India, DGCIS Annual Report, APEDA Agri Exchange and MSAMB [1]

\section{Statistical tools and techniques}

Statistical tools and techniques are used in this study to analyse the collected data efficiently and effectively and to draw certain conclusions. Graphical analysis, Trend analysis, descriptive statistics like mean, variance and standard deviation and ANOVA (Analysis of variance) has been used for testing the hypothesis.

The tools used by researcher include MATLAB R2019b, MS-Excel and Statistical Package for Social Science (SPSS) for analysis.

\section{Results and Discussion}

\section{Graphical analysis}

In the Figure.1 graph, researcher undoubtedly observes that Russia is the largest producer of Wheat in the world for the year 2019. 
Australia is second largest producer of wheat in the world for the year 2019. China is at third position whereas India is at fourth position in the world for the year 2019. Last year, India was at the second position. The researcher observes in the graph that there has been no drastic change in the production rate of wheat in India and China for 2019 with respect to previous year. Although Russia and Australia has shown a tremendous performance for 2019 , none other country has ever shown such an unexpected growth.

Table.1 International production of wheat in MT

\begin{tabular}{|l|l|l|l|l|l|l|l|}
\hline Country & $2019^{*}$ & $2018^{*}$ & $2017 \#$ & $2016 \#$ & $2015 \#$ & $2014 \#$ & $2013 \#$ \\
\hline China & 132000000 & 131430000 & 134340630 & 133278338 & 132646335 & 126215211 & 126215211 \\
\hline India & 102190000 & 99870000 & 98510000 & 92290000 & 86530000 & 95850000 & 93510000 \\
\hline Russia & 725000000 & 71685000 & 85863132 & 73294568 & 61785799 & 59711382 & 52100000 \\
\hline USA & 53892000 & 51287000 & 47370880 & 62833140 & 55839540 & 55147120 & 58104610 \\
\hline Canada & 33300000 & 32201000 & 29984200 & 32139900 & 37647400 & 27442100 & 37589100 \\
\hline Ukraine & 28700000 & 25057000 & 26208980 & 26098830 & 26532100 & 24113970 & 22279300 \\
\hline Pakistan & 25600000 & 25100000 & 26674000 & 25633000 & 25086174 & 25979399 & 24211360 \\
\hline Argentina & 20500000 & 19500000 & 18395106 & 11314952 & 13930078 & 9188339 & 8134409 \\
\hline Australia & 19000000 & 172980000 & 31818744 & 22274514 & 23742560 & 25303037 & 22855576 \\
\hline Turkey & 19000000 & 19000000 & 21500000 & 20600000 & 22600000 & 19000000 & 22050000 \\
\hline
\end{tabular}

\# Source: Food and Agriculture Organization Corporate Statistical Database, United States Department of Agriculture

Figure.1 International production of wheat in MT

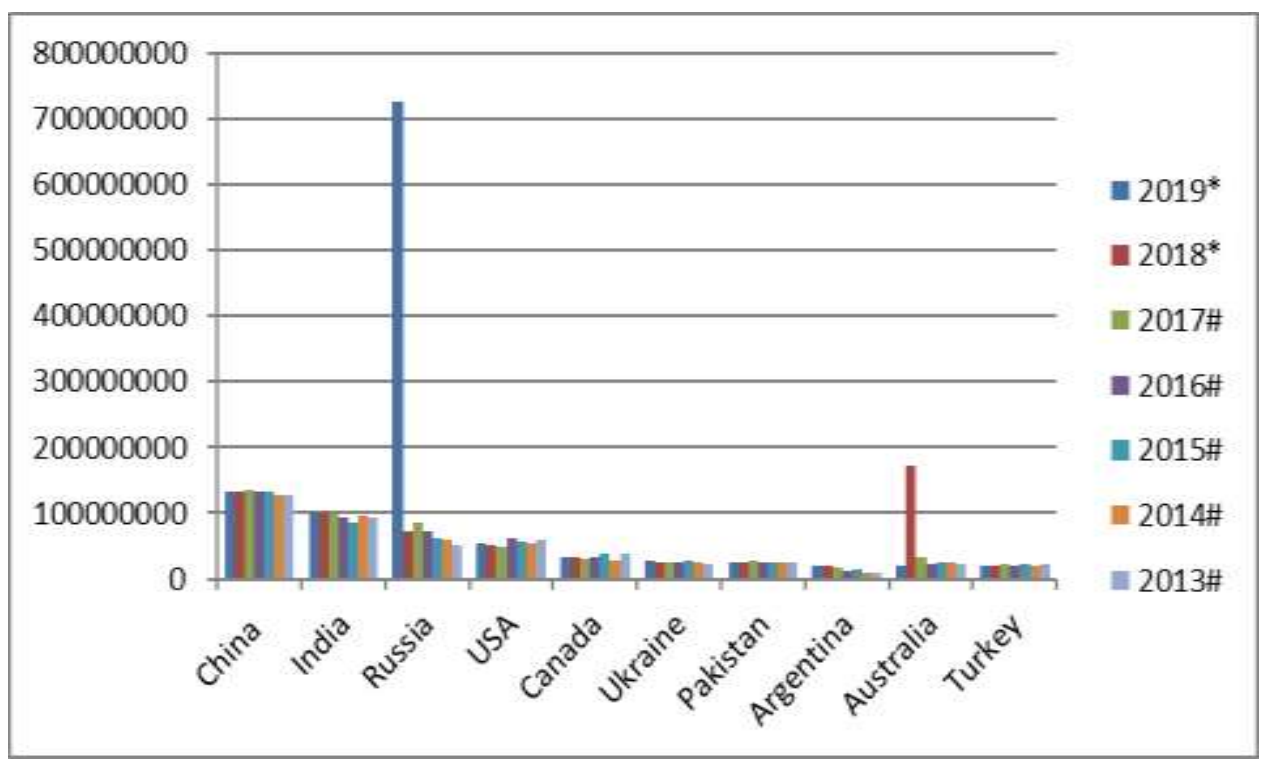


Table.2 Indian production of wheat (in MT)

\begin{tabular}{|l|l|}
\hline Year & Production (In MT) \\
\hline $\mathbf{2 0 1 3}$ & 93506000.00 \\
\hline $\mathbf{2 0 1 4}$ & 86530000.00 \\
\hline $\mathbf{2 0 1 5}$ & 92290000.00 \\
\hline $\mathbf{2 0 1 6}$ & 98510000.00 \\
\hline $\mathbf{2 0 1 7}$ & 99700000.00 \\
\hline $\mathbf{2 0 1 8}$ & 99870000.00 \\
\hline $\mathbf{2 0 1 9}$ & 102190000.00 \\
\hline
\end{tabular}

Source: Ministry of Agriculture, United States Department of Agriculture

Figure.2 Indian production of wheat

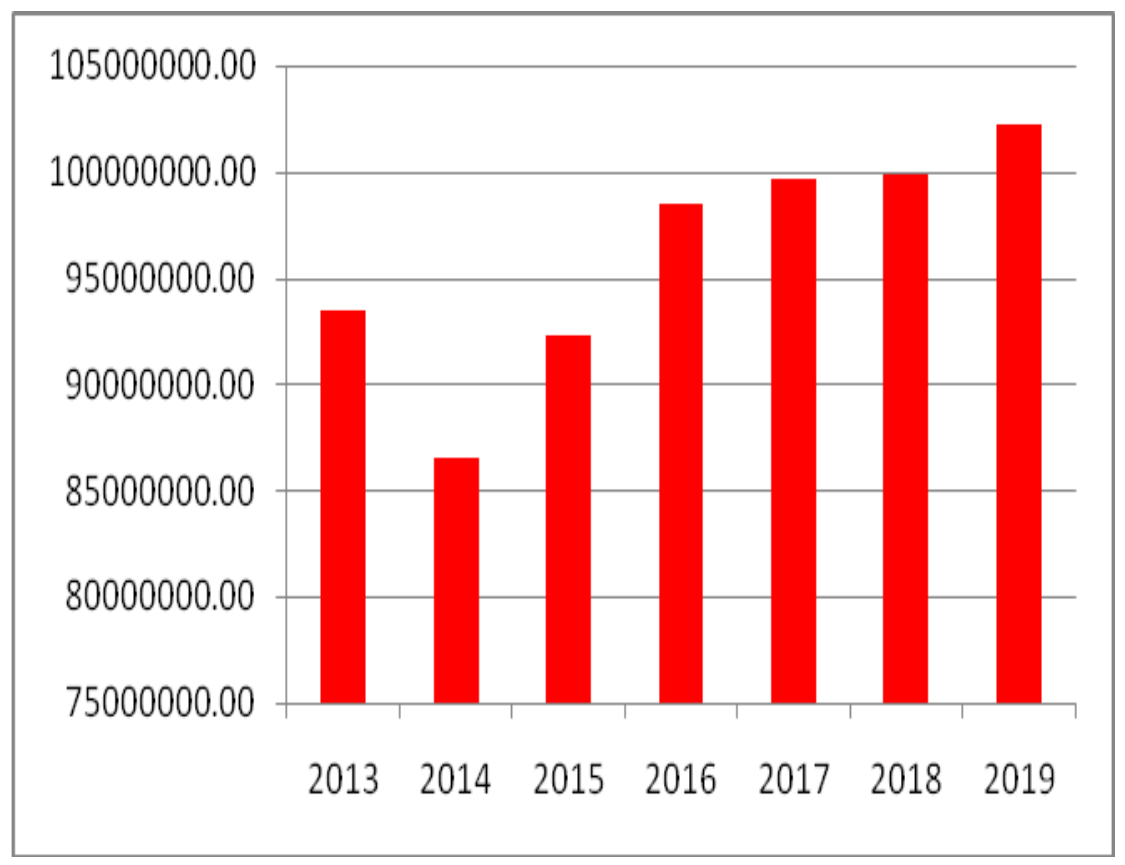

The international production of wheat in the year 2019-2020, as observed by US Department of Agriculture has been marked at 102190000.00 MT. In the year 2018-19, it was 99870000.00 MT. The trend of International Production of Wheat shows that the production of wheat has gradually increased over the years except for the years 2014-15 and 2015-16 which showed a decreased production from the previous year. Over the years, India has increased its production of Wheat, but still no drastic change has been observed over the years. 
Table.3 International export of wheat

\begin{tabular}{|l|l|l|l|l|l|l|l|l|}
\hline S.No. & Country & $\mathbf{2 0 1 9}$ & $\mathbf{2 0 1 8}$ & $\mathbf{2 0 1 7}$ & $\mathbf{2 0 1 6}$ & $\mathbf{2 0 1 5}$ & $\mathbf{2 0 1 4}$ & $\mathbf{2 0 1 3}$ \\
\hline $\mathbf{1}$ & Russia & $3,40,00,000$ & $2,52,84,650$ & $2,28,26,883$ & $1,43,47,955$ & $96,03,489$ & $1,92,08,991$ & $86,04,707$ \\
\hline $\mathbf{2}$ & United States & $2,65,35,000$ & $1,48,61,600$ & $2,29,20,928$ & $2,04,55,939$ & $1,71,03,279$ & $2,20,36,423$ & $2,66,08,333$ \\
\hline $\mathbf{3}$ & Canada & $2,45,00,000$ & $1,55,79,1632,05,15,764$ & $1,77,71,439$ & $1,92,14,5882,05,89,954$ & $1,67,39,204$ \\
\hline $\mathbf{4}$ & Ukraine & $1,95,00,000$ & $1,01,78,353$ & $1,27,63,233$ & $1,29,59,011$ & $86,68,170$ & $62,12,742$ & $40,05,953$ \\
\hline $\mathbf{5}$ & Argentina & $1,45,00,000$ & $94,67,673$ & $1,14,65,385$ & $84,79,903$ & $43,97,111$ & $16,08,259$ & $30,26,806$ \\
\hline $\mathbf{6}$ & Australia & $1,05,00,000$ & $90,85,496$ & $1,93,12,367$ & $1,35,53,137$ & $1,43,67,717$ & $1,53,03,591$ & $1,25,68,288$ \\
\hline $\mathbf{7}$ & Turkey & $65,00,000$ & $63,50,000$ & 85,201 & 88,403 & 66,803 & $7,42,221$ & $3,94,756$ \\
\hline $\mathbf{8}$ & Kazakhstan & $52,00,000$ & $15,16,856$ & $90,00,000$ & $74,00,000$ & $10,02,500$ & $18,41,361$ & $33,70,047$ \\
\hline $\mathbf{9}$ & China & $13,00,000$ & $14,23,000$ & $1,39,119$ & 13,920 & 3,167 & $2,70,201$ & 52,078 \\
\hline $\mathbf{1 0}$ & Serbia & $12,00,000$ & $5,21,685$ & $2,22,844$ & $4,41,388$ & $10,77,000$ & $3,78,379$ & $4,90,022$ \\
\hline $\mathbf{1 1}$ & India & $5,00,000$ & $4,94,000$ & 517000 & $4,09,000$ & $9,06,000$ & $18,34,000$ & $54,01,000$ \\
\hline
\end{tabular}

Source: UN Comtrade, as reported by importing countries

Figure.3 International export of wheat

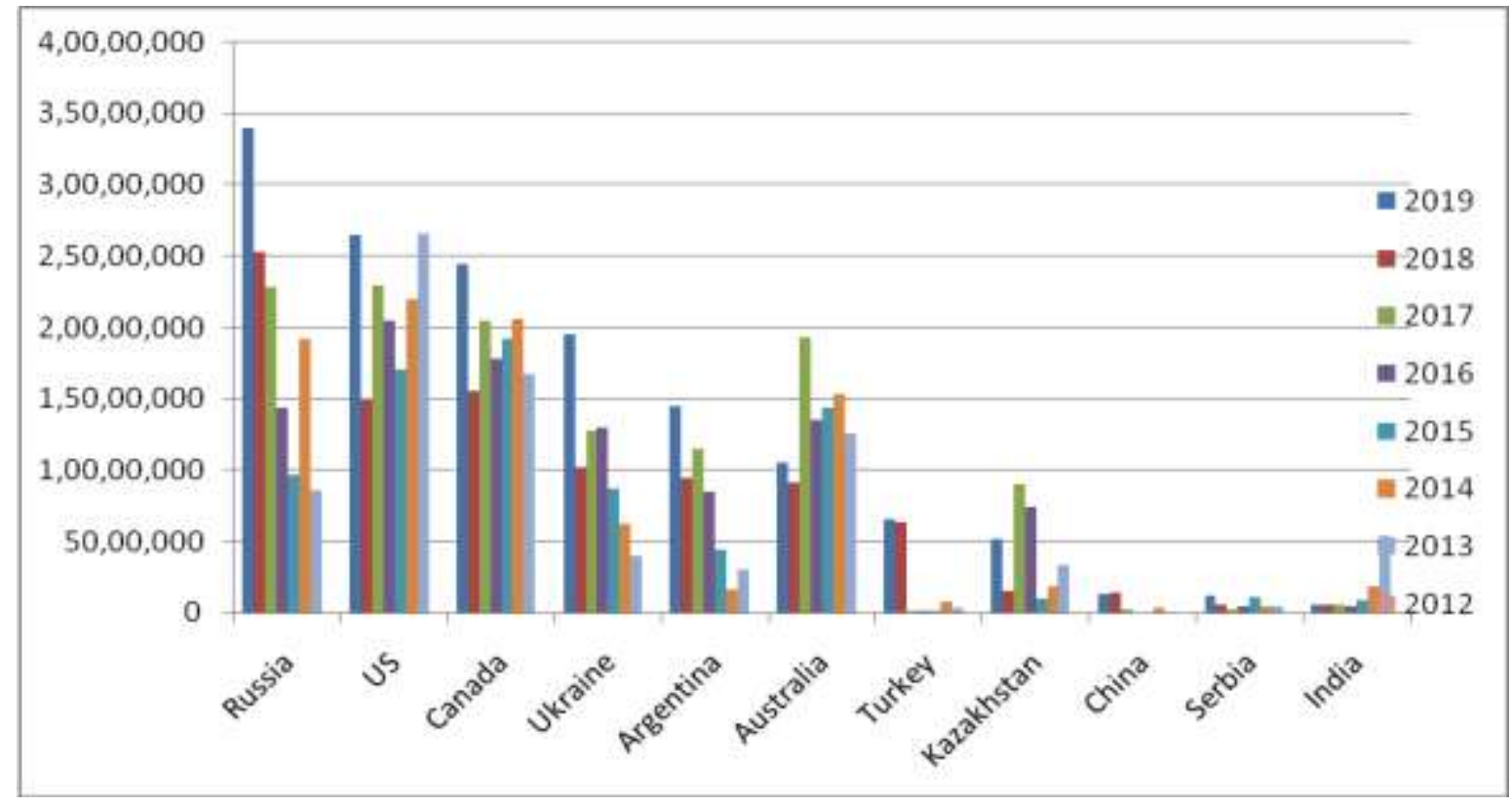

The export of wheat on the global platform shows a different trend every year. None of the countries are able to maintain their positions. This year, Russia has emerged out to be the largest exporter of wheat. This was the same trend in the years 2018 and 2017. In the year 2013, 2014 and 2016 United states was the major wheat exporting country. In the year 2015 Canada had emerged at the top. In comparison to India all the above mentioned countries have shown a remarkable export of wheat except Turkey which has increased its export in the last 2 years only. The export trend in China has also gained popularity in the last 2 years only. Till 2016, China and India's export had a large difference but within 3 years, export of wheat in China has far increased in comparison to India 
Table.4 India's export of wheat

\begin{tabular}{|l|l|l|}
\hline Years & Quantity (in MT) & Values in Lakhs \\
\hline $\mathbf{2 0 1 3}$ & $55,62,374.75$ & $9,26,161.06$ \\
\hline $\mathbf{2 0 1 4}$ & $29,24,070.18$ & $4,99,183.96$ \\
\hline $\mathbf{2 0 1 5}$ & $6,66,668.96$ & $1,06,177.26$ \\
\hline $\mathbf{2 0 1 6}$ & $2,65,606.04$ & $44,785.02$ \\
\hline $\mathbf{2 0 1 7}$ & $3,22,790.13$ & $62,437.19$ \\
\hline $\mathbf{2 0 1 8}$ & $2,26,225.00$ & $42,494.69$ \\
\hline
\end{tabular}

Source: DGCIS Annual Report

Figure.4 India's export of wheat

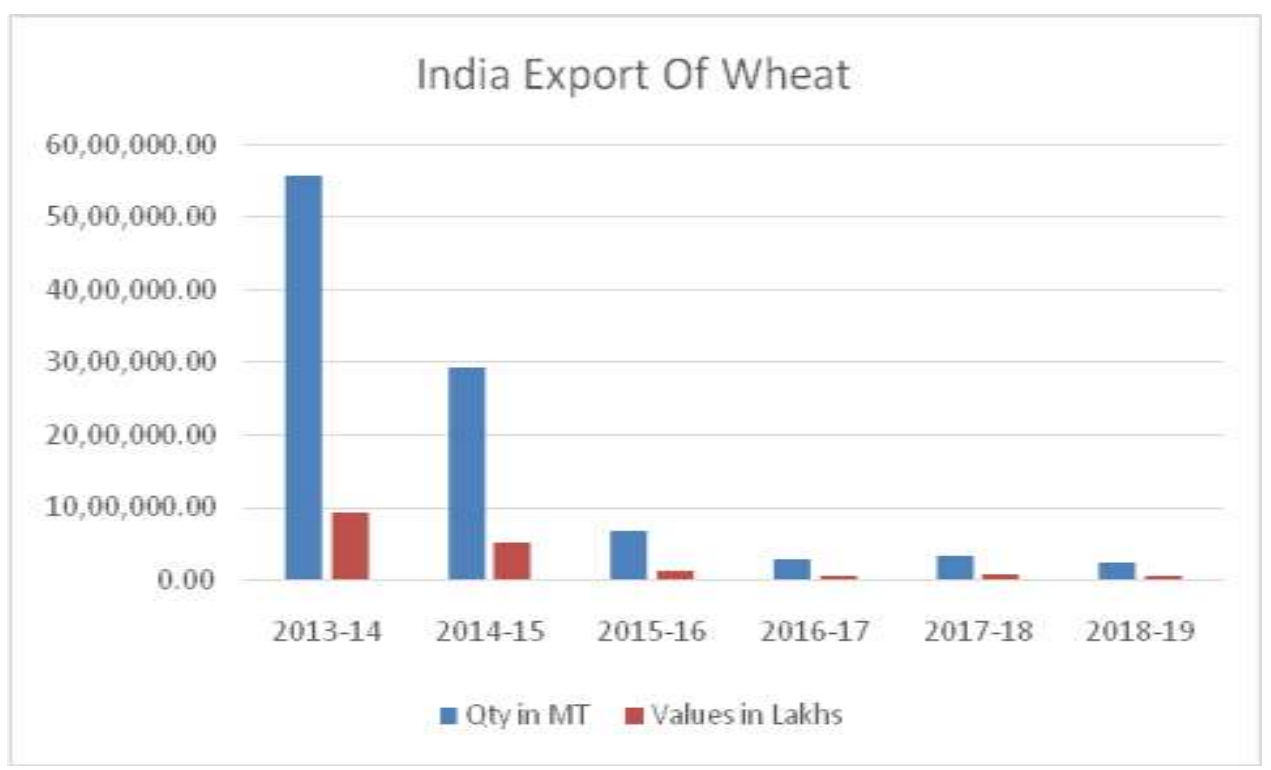

India's export of wheat has decreased over the years. The year 2013 marked the highest export of wheat with 55,62,374.75 MT and 2018 has marked the least with 2,26,225.00 MT. Every year the export of wheat is getting decreased, except in 2017 where the export had increased over the previous year. India's export has seen a drastic decrease in these years.

\section{Trend analysis}

Trend analysis is an estimation technique used in stock market pricing. It uses older data to predict the future values of any data. A polynomial equation is predicted according to the data available so that the data can be treated as a function. More the data availability, lesser redundancies in the data, more accurate the result will be. The $\mathrm{R}^{2}$ value will help to check whether the polynomial equation predicted actually fits the data or not. If the value of $R^{2}>0.80$, then the polynomial equation fits the data accurately otherwise the curve fitting function has to be changed.

Here the trend analysis will help to understand the production of wheat and export of wheat in India more precisely. 
Figure.5 Curve fitting for Indian production of wheat

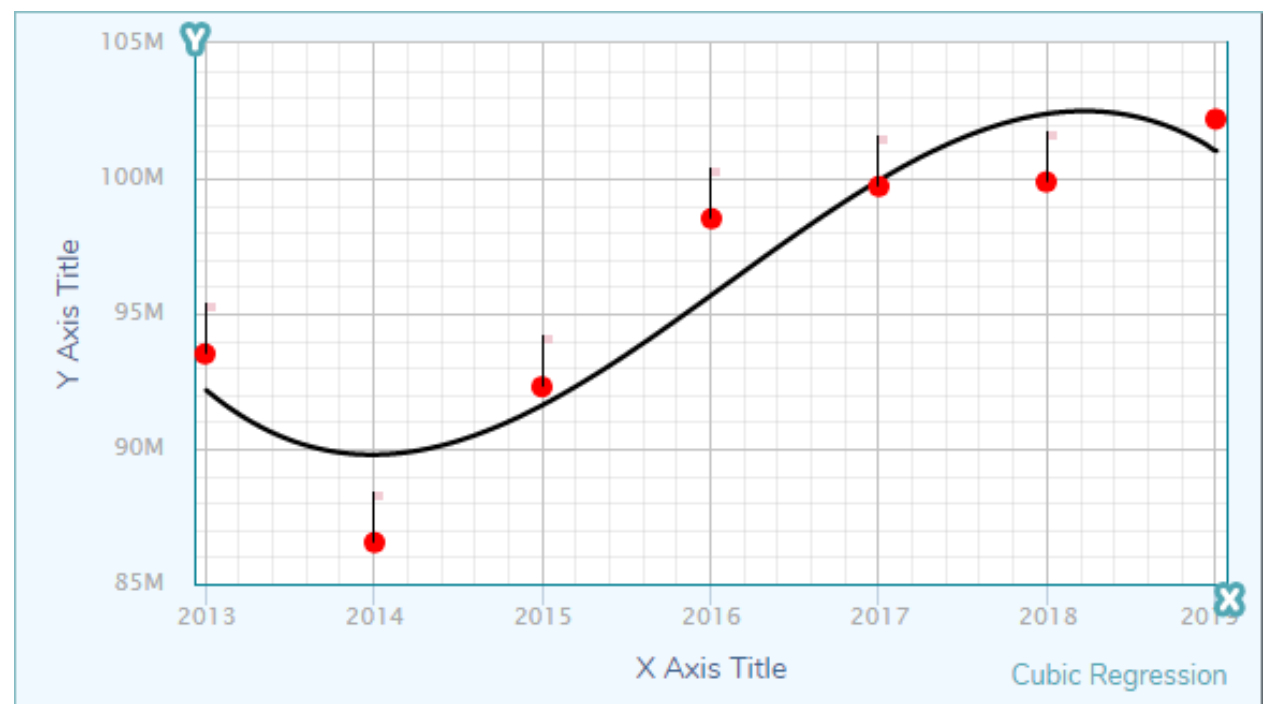

Curve fitting for Table 2: Indian Production of $\mathrm{y}=274660200000000-4087011000000 * \mathrm{x}+$ Wheat has yielded cubic regression as shown $2027189000 * \mathrm{x}^{2}-335166.7 * \mathrm{x}^{3}$. The $\mathrm{R}^{2}$ value in Figure No. 5.The polynomial equation of 0.8436 shows that the polynomial equation governing the production of wheat in India is mentioned fits the data accurately.

Figure.6 Curve fitting for Indian export of wheat

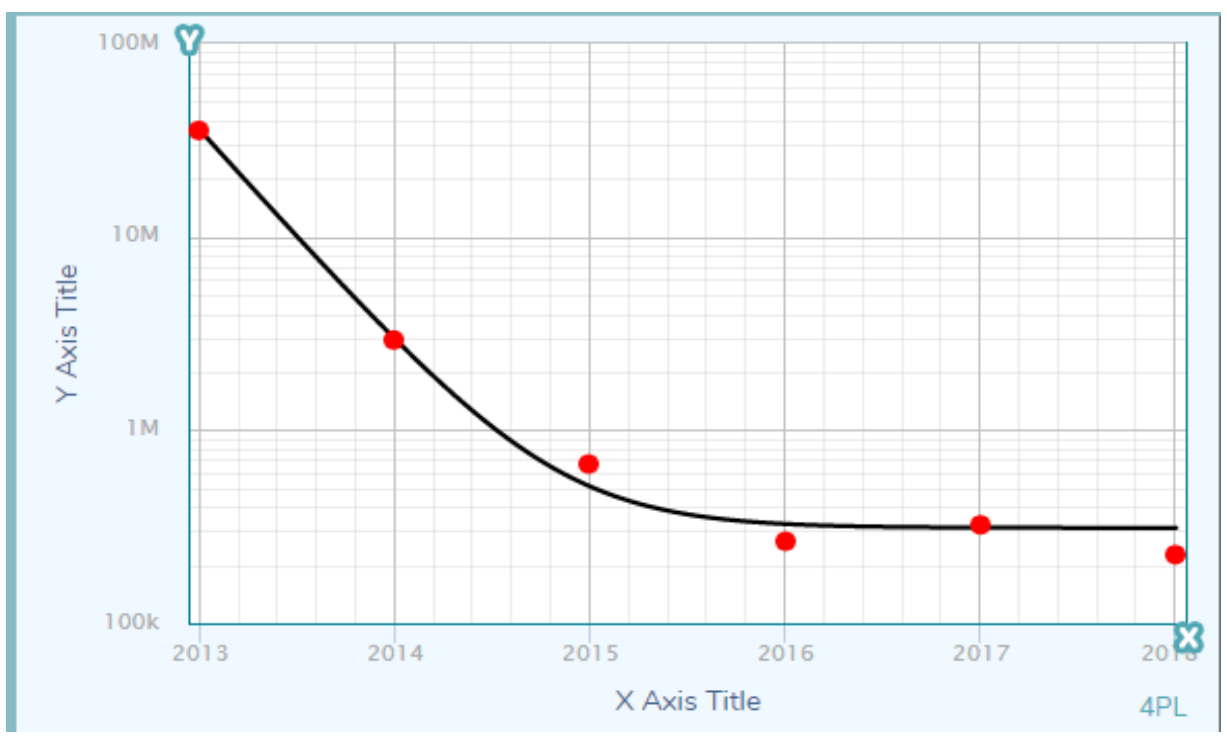

\section{Observations}

Curve Fitting for Table 4: Indian Export of Wheat has yielded 4 parameter logistic regression (4PL) as shown in Figure 5. The polynomial equation governing the production of wheat in India is $\mathrm{y}=311530.6+$ $(22315690000000-311530.6) /(1+$ $\left.(\mathrm{x} / 2007.855)^{\wedge} 5220.578\right)$. The $\mathrm{R}^{2}$ value of 1.0 show that the polynomial equation mentioned perfectly fits the data. It can be observed that the export of wheat has shown a negative 
trend over the years with highest export marked in 2013 and least in 2018.

\section{ANOVA (Analysis of variance)}

Analysis of Variance (ANOVA) gives a statistical test and is an explanatory tool to help check whether 2 or more samples have a significant difference in their means or not. ANOVA is based on the law of variance. Here, the researcher uses ANOVA to understand the analytical relationship between Production and Export of Wheat in India.

Table.7 Data used for ANOVA (Export and Production of wheat in 1000MT)

\begin{tabular}{|c|c|c|c|c|c|c|}
\hline \multicolumn{7}{|c|}{ Data Summary } \\
\hline & \multicolumn{6}{|l|}{ Samples } \\
\hline & $\begin{array}{l}\text { Export of } \\
\text { Wheat from } \\
\text { India }\end{array}$ & $\begin{array}{l}\text { Production } \\
\text { of Wheat in } \\
\text { India }\end{array}$ & 3 & 4 & 5 & Total \\
\hline $\mathbf{N}$ & 6 & 6 & & & & 12 \\
\hline$-\Sigma X$ & 9967.79 & 570406 & & & & 580373.79 \\
\hline -Mean & 1661.2983 & 95067.6667 & & & & 48364.4825 \\
\hline $\begin{array}{ll}- & X 2\end{array}$ & 40160556.5 & $\begin{array}{l}543665840 \\
3\end{array}$ & & & & $\begin{array}{l}544067445 \\
9\end{array}$ \\
\hline Variance & 4720216.73 & 27883312.6 & & & & $\begin{array}{l}239429696 \\
2\end{array}$ \\
\hline Std.Dev. & 2172.606 & 5280.4652 & & & & 48931.5538 \\
\hline Std.Err. & 886.9627 & 2155.7409 & & & & 14125.3229 \\
\hline
\end{tabular}

Table.8 Results from ANOVA

\begin{tabular}{|l|l|l|l|l|l|}
\hline \multicolumn{2}{|l|}{ Results from ANNOVA (Summary) } & & & \\
\hline Source & SS & Df & MS & F & P \\
\hline $\begin{array}{l}\text { Analysis } \\
\text { (Between } \\
\text { Groups) }\end{array}$ & 26174248935.6 & 1 & 26174248935.6 & 1605.61 & $<.001$ \\
\hline
\end{tabular}

The results from ANOVA have been shown in Table 8 . The value of $\mathrm{p}<0.001$ proves that the two samples are statistically highly significant. This rejects the null hypothesis with which the researcher started his study and proves the alternative hypothesis: India is one of the largest producers of wheat in the world but as compared to production, India is not a very big exporter of wheat.

In conclusion, the data analysis conducted in this research shows that there is a significant difference in the production of wheat and export of wheat in India. Also, the export of wheat from India has decreased over the years whereas the production of wheat has not shown any significant increase. Other countries like Russia, US and Canada have increased their exports by a drastic amount in the year 2019 with respect to the previous years. India too needs to consider this and work upon its export strategies to increase the export of wheat as compared to the production of wheat it has. 


\section{References}

1. Kumar, Anuj; Poswal, Randhir; Singh, Gyanendra; Sharma, Ramesh; Saharan, Mahender; Chhokar, R.S; Ramadas, Sendhil; Chand, Ramesh; Sharma, Indu. (2014). Wheat Cultivation in India (Pocket Guide).

2. Oyewole, Charles. (2016). The wheat crop. 10.13140/RG.2.2.13776.92164.

3. Grewal S, Goel S. 2015. Current research status and future challenges to wheat production in India. Indian $J$ Biotechnol., 14: 445-54.

4. Mouhamadou Thile Sow1, "Using ANOVA to Examine the Relationship between Safety \& Security and Human Development" Journal of International Business and Economics, December 2014, Vol. 2, No. 4, pp. 101-106.

5. International Trade Centre, Trade Map. Accessed on Sept 16, 2019.

6. Investopedia, Net Exports Definition. Accessed on Sept 17, 2019.

7. The World Factbook, Field Listing: Imports - Commodities, Central Intelligence Agency. Accessed on
Sept 18, 2019.

8. APEDA, Annual Reports and Statistics on exports of Agricultural commodities from India Import \& Export Database, Ministry of Commerce and Industry, Government of India, Accessed on Sept 14, 2019.

9. Limbore, Nilesh. (2015). AN Analytical study of Indian agriculture crop production and export with reference to wheat. Review of Research 2249-894X Impact points 3.1402(UIF). Volume 4. 11.

10. United Nations. 2003. UN comtrade. http://comtrade.un.org/ Accessed on Sept 14, 2019

11. Agropedia: Agricultural Portal developed under the sponsorship of ICAR, NAIP. Accessed on Sept 12, 2019.

12. Limbore N.V. and Mane B.S. (2014), A Study of Banking Sector in India and Overview of Performance of Indian Banks with Reference to Net Interest Margin and Market Capitalization of Banks, Review of Research, 3(6), 111.

\section{How to cite this article:}

Tarandeep Singh. 2019. An Analytical Study on the Production and Export of Indian Agricultural Crop with Reference to Wheat. Int.J.Curr.Microbiol.App.Sci. 8(10): 1974-1982. doi: https://doi.org/10.20546/ijcmas.2019.810.230 